\title{
EFFECT OF MINIMUM QUANTITY LUBRICATION ON SURFACE ROUGHNESS IN TOOL-BASED MICROMILLING
}

\author{
Mohammad YeakUb Ali", Wan Norsyazila JaIlani, MOHAMEd ABD \\ RAHMAN, MUHAMMAd HASibul HASAN AND ASFANA BANU \\ Department of Manufacturing and Materials Engineering, \\ Faculty of Engineering, \\ International Islamic University Malaysia, \\ Jalan Gombak, 53100 Kuala Lumpur, Malaysia. \\ *Corresponding author: mmyali@iium.edu.my
}

(Received: 26 $6^{\text {th }}$ Feb. 2016; Accepted: 22 $2^{\text {nd }}$ Jan. 2017; Published online: 30th May 2017)

\begin{abstract}
Cutting fluid plays an important role in machining processes to achieve dimensional accuracy in reducing tool wear and improving tool lifespan. The conventional flood cooling method in machining processes is not cost effective and consumption of huge amounts of cutting fluid is neither healthy nor environmentally friendly. In micromachining, flood cooling is not recommended to avoid possible damage to the microstructures. Therefore, one of the alternatives to overcome the environmental issues is to use a minimum quantity of lubrication (MQL) in the machining process. MQL is ecofriendly and has an economical advantage in manufacturing costs. However, there is an observed lack of study on MQL in improving machined surface roughness in micromilling. A study of the effects of MQL on surface roughness should be carried out because surface roughness is one of the important issues in micromachined parts such as microfluidic channels. This paper investigates and compares surface roughness with the presence of MQL and dry cutting in the micromilling of aluminium alloy 1100 using a DT-110 milling machine. The relationship between the depth of cut, feed rate, and spindle speed on surface roughness is also analyzed. The three machining parameters identified as significant for surface roughness with dry cutting are: depth of cut, feed rate, and spindle speed. For surface roughness with MQL, it is found that spindle speed did not greatly influence surface roughness. The presence of MQL provides a better surface roughness by decreasing the friction between tool and work piece.
\end{abstract}

ABSTRAK: Cecair pemotongan memainkan peranan yang penting dalam proses pemesinan untuk mencapai ketepatan dimensi dalam mengurangkan kehausan alat dan mempertingkatkan jangka hayat alat. Kaedah konvensional penyejukan banjir dalam proses pemesinan tidak efektif kos dan penggunaan jumlah cecair pemotongan yang besar adalah tidak sihat dan tidak mesra alam. Dalam pemesinan mikro, penyejukan banjir tidak digalakkan untuk mengelakkan kerosakan kepada struktur mikro. Oleh itu, salah satu alternatif untuk mengatasi isu alam sekitar adalah dengan menggunakan kuantiti pelinciran (MQL) yang minimum dalam proses pemesinan. MQL adalah mesra alam dan adalah lebih baik dari segi menjimatkan kos pembuatan. Walau bagaimanapun, tidak banyak pengajian mengenai bagaimana MQL dapat memperbaiki kekasaran dipermukaan mesin dalam pengisaran mikro. Satu kajian mengenai kesan MQL pada kekasaran di permukaan perlu dijalankan kerana kekasaran di permukaan adalah salah satu isu penting pada bahagian mikromesin seperti saluran microfluidic. Kertas ini mengkaji dan membandingkan kekasaran permukaan dengan kehadiran MQL dan pemotongan kering dalam pengisaran mikro aloi aluminium 1100 menggunakan mesin pengilangan DT-110. Hubungan antara ketebalan pemotongan, kadar suapan dan kelajuan gelendong pada kekasaran permukaan 
juga dianalisis. Tiga parameter pemesinan yang dikenal pasti sebagai penting untuk mempengaruhi kekasaran pada permukaan dengan pemotongan kering adalah: ketebalan pemotongan, kadar suapan dan kelajuan gelendong. Untuk kekasaran pada permukaan dengan MQL, didapati bahawa kelajuan gelendong tidak kuat mempengaruhi kekasaran pada permukaan. Kehadiran MQL memberi kekasaran pada permukaan yang lebih baik dengan mengurangkan geseran antara alat dan bahan kerja.

KEYWORDS: micromilling; minimum quantity lubrication (MQL); surface roughness; dry cutting; metal working fluids (MWFs); microlubrication

\section{INTRODUCTION}

The increasing demands for miniaturized products, especially in the biomedical, electronics, and aerospace industries, have obliged manufacturers to fabricate complex micro-parts with high accuracy. One of the fast developing microfabrication methods is micropatterning, which has a broad application in cell biology and biodegradable implantable medical devices. The micropatterning method can be conducted by several micromachining processes such as electron beam etching, soft lithography, laser micromachining, micromilling, etc. Micromilling is one of the flexible mechanical micromachining processes that are capable for producing three dimensional (3D) miniaturized parts. It is characterized by the mechanical interaction between a sharp edged microtool and a workpiece material. Micromilling is similar to macro milling except for the tool size it employs [1-6].

Micromilling can be used to drill holes, slots, and pockets on workpieces. However, the micromilling process leads to high friction between the tool and the workpiece, resulting in high temperature and damaging the dimensional accuracy and surface quality of the product. Hence, in order to reduce these problems, avoid chips, and reduce the adhesion at the toolworkpiece interface, cutting fluids are used in the machining operation [7, 8]. Without the cutting fluid, the temperature of the tool and the workpiece would increase since the heat carried away from the cutting zone would be decreased [9].

During the machining operation, cutting fluids or metalworking fluids (MWFs) are widely used. The main objectives are to cool and lubricate the machined surface, flush away the unwanted chips, and restrain corrosion. Better tool life and better work quality with effective chip management are some of the advantages of the MWFs [10,11]. Due to these advantages, MWFs are seeing increased utilization in the machining industry. Since most of the MWFs are petroleum-based oils, they need to be treated and disposed of every year and the cost to treat the waste is extensive. In addition, inadvertent environmental contamination, digestive system problems, cancer, and adverse respiratory effects in workers may result in the ineffective disposal of MWFs and cutting fluid toxicity [10]. Exposure to large amounts of cutting fluid, through either inhalation of skin contact, will cause adverse effects [12]. Thus, in order to protect the environment and lower costs, it is crucial to decrease the usage of MWFs in machining as much as possible and keep pace with green manufacturing. The more frequently used approaches to green manufacturing relating to MWFs are dry cutting and minimum quantity lubrication (MQL) $[11,13]$.

The MQL method has been accepted as a prominent alternative in machining because of its environmentally-friendly characteristics. However, it requires special machining and cutting tool setups $[11,13,14]$. MQL, known as the "micro-lubrication" and "near-dry machining" $[15,16]$, refers to a small amount of cutting fluid $(2-100 \mathrm{ml} / \mathrm{hr})$ in the form of aerosol being delivered to the tool-to-workpiece interface. MQL may also refer to use of cutting fluids in tiny quantities $[12,15,17]$. The lubricant does not recirculate through the 
lubrication system since it is almost all evaporated at the point of application. Yet, it is vital to ensure an efficient extraction of aerosol from the machine. In MQL, the lubrication is obtained via the lubricant and the cooling is achieved by pressurized air that reaches the cutting surface. MQL also helps to reduce the induced thermal shock and increases the workpiece surface integrity when the tool is at high pressure $[15,17]$. The objective of this paper is to investigate and compare surface roughness with the presence of MQL and dry cutting in micromilling of aluminum alloy 1100. The comparison between surface roughness in micromilling in MQL and the dry cutting processes is presented.

\section{EXPERIMENT AND MEASUREMENT}

The micromilling operation in this experiment is conducted using a miniature machine known as Integrated Multi-purpose Machine Tools (DT-110, Microtools Inc., Singapore). This machine has three travel axes which are the X, Y, and Z-axes, for greater flexibility and more accuracy. This machine is an ultra-precision milling machine with submicron accuracies. After machining the workpiece with a two flute end mill, surface roughness is measured by the Mitutoyo Surface test SJ-400.

A Bluebe FK-type MQL system is used in this experiment to apply MQL. Bluebe FKtype is equipped with a highly accurate variable pump. It transfers air and lubricant to the nozzles which can be adjusted separately. Lubricant consumption is as little as 4-8 ml per hour per nozzle and the lubricant spouting from the nozzles is barely visible. Fig. 1 shows the miniature machine tools (DT-110) and the Bluebe FK-type that are used in this research. The cutting fluid from nozzle is directed to the micro end mill. The lubrication that is used with the MQL system is an Accu-Lube LB-2000 (LB-1). The Accu-Lube LB-2000 is natural-based fluid lubrication for MQL. It is manufactured using non-toxic, renewable raw materials and biodegradable ingredients. Then, it is extracted and blended on the basis of vegetable oils. It does not contain hazardous chemicals. Therefore, it is environmentally safe and biodegradable. It is safe to be used with all metals without any damage [15].

The tool material that is used in this experiment is tungsten carbide. The use of tungsten carbide as a tool material is important because it has high hardness and strength at high temperatures [18]. The selected work material is aluminum alloy 1100 . The dimension of the aluminum is $80 \mathrm{~mm} \times 20 \mathrm{~mm} \times 5 \mathrm{~mm}$. It is selected because of its excellent comprehensive performance which is thermally stable, high strength and a lightweight microcomponent.

The slotting of the workpieces are done with an end mill of $0.5 \mathrm{~mm}$ in diameter with two different depths of cut, feed rates, and spindle speeds as shown in Table 1. After the preliminary tests, the machining is performed under different cutting conditions, as shown in Table 1. For this experiment, the cutting parameters of depth of cut, feed rate, and spindle speed are chosen to be variable. Design Expert software with two factorial levels is used to analyze the surface roughness. From this model, eight experiments need to be conducted with varied parameters and levels. For dry cutting, the same cutting conditions are also applied as shown in Table 1. 
Table 1: Cutting conditions

\begin{tabular}{lcc}
\hline Machining Parameters & \multicolumn{2}{c}{ Values } \\
\hline & Level-I & Level-II \\
\cline { 2 - 3 } A: Depth of cut (mm) & 0.05 & 0.15 \\
B: Feed rate (mm/min) & 1 & 2 \\
C: Spindle speed (rpm) & 2000 & 2800 \\
Machining length (mm) & \multicolumn{2}{c}{12} \\
Work material & \multicolumn{2}{c}{ Aluminum alloy 1100} \\
\hline
\end{tabular}

Table 2: Experimental results of surface roughness with dry cutting and MQL

\begin{tabular}{cccccc}
\hline No. & $\begin{array}{c}\text { A: } \\
\text { Depth } \\
\text { of cut } \\
(\mathbf{m m})\end{array}$ & $\begin{array}{c}\text { B: Feed } \\
\text { rate } \\
(\mathbf{m m} / \mathbf{m i n})\end{array}$ & $\begin{array}{c}\text { C: } \\
\text { Spindle } \\
\text { speed } \\
(\mathbf{r p m})\end{array}$ & $\begin{array}{c}\text { Surface } \\
\text { roughness } \\
\text { with dry } \\
\text { cutting } \\
(\boldsymbol{\mu m})\end{array}$ & $\begin{array}{c}\text { Surface } \\
\text { roughness } \\
\text { with } \\
\mathbf{M Q L} \\
(\boldsymbol{\mu m})\end{array}$ \\
\hline 1 & 0.05 & 1 & 2000 & 0.10 & 0.14 \\
2 & 0.15 & 1 & 2000 & 0.15 & 0.15 \\
3 & 0.05 & 2 & 2000 & 0.19 & 0.18 \\
4 & 0.15 & 2 & 2000 & 0.20 & 0.19 \\
5 & 0.05 & 1 & 2800 & 0.17 & 0.12 \\
6 & 0.15 & 1 & 2800 & 0.18 & 0.19 \\
7 & 0.05 & 2 & 2800 & 0.21 & 0.18 \\
8 & 0.15 & 2 & 2800 & 0.27 & 0.21 \\
\hline
\end{tabular}
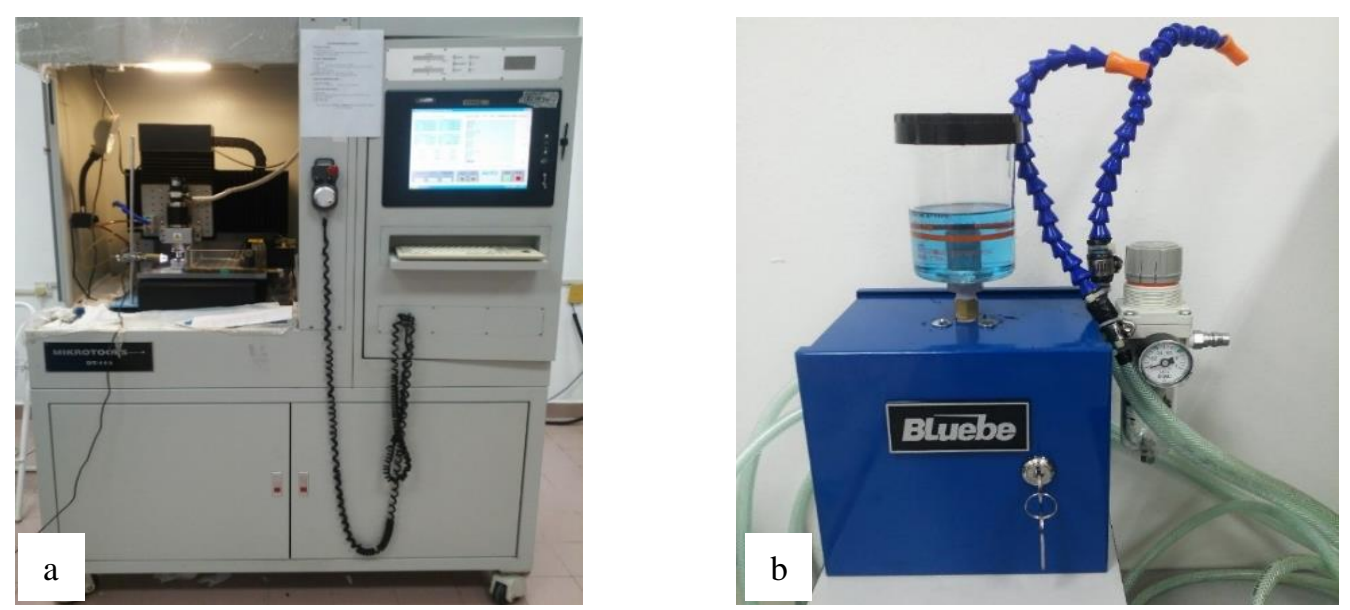

Fig. 1: (a) Integrated multipurpose machine Tools (DT-110) and (b) minimum quantity lubrication system (Bluebe FK).

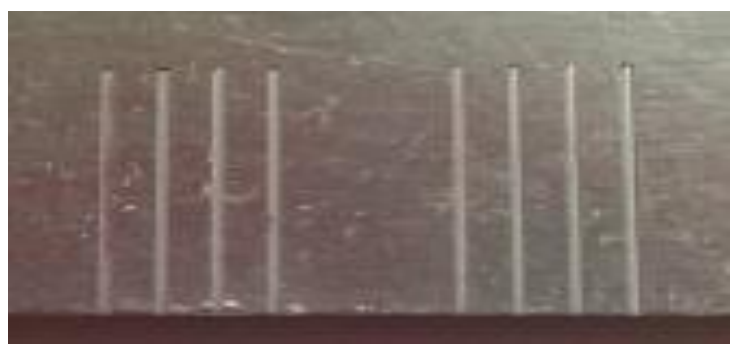

Fig. 2: Selected machined microchannels on aluminum alloy 1100. 


\section{RESULTS AND DISCUSSION}

Figure 2 shows the eight machined workpiece microchannels after the machining process. Table 2 shows the experimental result of surface roughness with dry cutting and MQL of the micromilling process. The range of surface roughness with dry cutting is from 0.10 to $0.27 \mu \mathrm{m}$ and for surface roughness with MQL is from 0.14 to $0.21 \mu \mathrm{m}$.

ANOVA, as shown in Table 3, of surface roughness in dry cutting showed a "Model F-value" of 19.98 which shows the model is significant. There is only a $0.72 \%$ chance that the "Model F-Value" could occur due to noise. Values of "Prob > F" less than 0.05 indicate that model terms of depth of cut (A), feed rate (B), and spindle speed (C) are significant model terms. Based on the Table 3, feed rate (B) is the most significant parameter that affected the surface roughness with dry cutting followed by spindle speed (C) and depth of cut (A). The "Pred R-Squared" of 0.7498 is in reasonable agreement with the "Adj RSquared" of 0.8905 . The adjusted R-squared is particularly useful when comparing models with different numbers of terms. However, this comparison is done in the background when model reduction has taken place. "Adeq Precision" measures the signal to noise ratio. A ratio greater than 4 is desirable. Thus, in this analysis, the ratio of 12.875 indicates that the "Adeq Precision" is an adequate signal. So, the model can be used to navigate the design space.

Table 3: ANOVA of surface roughness with dry cutting

\begin{tabular}{lccccc}
\hline Source & $\begin{array}{c}\text { Sum of } \\
\text { Squares }\end{array}$ & DF & $\begin{array}{c}\text { Mean } \\
\text { Square }\end{array}$ & $\begin{array}{c}\text { F- } \\
\text { Value }\end{array}$ & Prob > F \\
\hline Model & 0.016 & 3 & 5.246 E-003 & 19.98 & 0.0072 \\
A-Depth of cut & $2.112 \mathrm{E}-003$ & 1 & $2.112 \mathrm{E}-003$ & 8.05 & 0.0470 \\
B-Feed rate & $9.112 \mathrm{E}-003$ & 1 & $9.112 \mathrm{E}-003$ & 34.71 & 0.0041 \\
C-Spindle speed & $4.512 \mathrm{E}-003$ & 1 & $4.512 \mathrm{E}-003$ & 17.19 & 0.0143 \\
Residual & $1.050 \mathrm{E}-003$ & 4 & $2.625 \mathrm{E}-004$ & & \\
Cor Total & 0.017 & 7 & & & \\
\hline Pred R-Squared & & 0.7498 & Adj R-Squared & 0.8905 \\
Adeq Precision & & 12.875 & & & \\
\hline
\end{tabular}

Figure 3a shows the contour plot between depth of cut (A) and feed rate (B) on surface roughness for dry cutting. From the graph, when depth of cut is $0.05 \mathrm{~mm}$ and feed rate is $1.25 \mathrm{~mm} / \mathrm{min}$, the surface roughness is $0.15 \mu \mathrm{m}$ and while depth of cut is $0.15 \mathrm{~mm}$ and feed rate is $1.75 \mathrm{~mm} / \mathrm{min}$, the surface roughness is $0.22 \mu \mathrm{m}$. This shows that as the depth of cut and feed rate increase, higher surface roughness will result. The empirical model for $R_{a}$ surface roughness for dry cutting is shown by Eqn. 1, where $A=$ Depth of cut (mm), $B=$ Feed rate $(\mathrm{mm} / \mathrm{min})$, and $C=$ Spindle speed $(1000 \mathrm{rpm})$.

$$
\left(R_{a}\right)_{\mathrm{dry}}=-0.093+0.33 A+0.068 B+0.06 C
$$

ANOVA, as shown in Table 4, of surface roughness with MQL showed an F-value for the model of 11.25. It indicates that the model is significant. There is only a little chance (3.76\%) that the model F-Value of 11.25 could occur due to noise. Values of "Prob > F" less than 0.05 indicate that the model terms are significant. In this case depth of cut (A) and feed rate (B) are significant model terms. Based on Table 4, feed rate (B) is the most significant parameter that affected the surface roughness with MQL followed by the depth of cut (A). The "Pred R-Squared" of 0.5556 is not as close to "Adj R-Squared" of 0.8542 as 
one might normally expect. "Adeq Precision" of 9.859 indicates that the signal to noise ratio is an adequate signal.
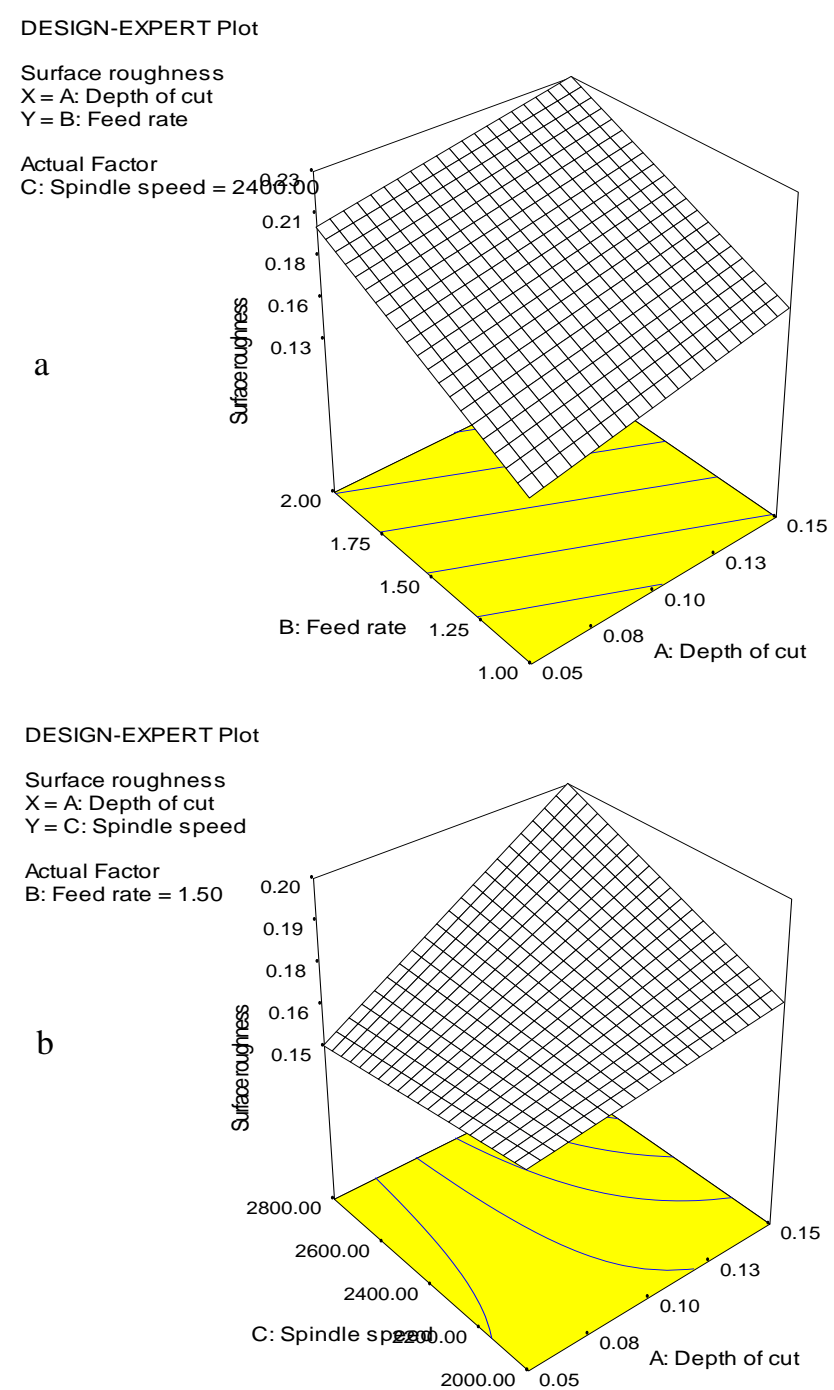

Fig. 3: Three dimensional plot of depth of cut and feed rate on surface roughness in (a) dry cutting, and (b) cutting with MQL.

Table 4: ANOVA of surface roughness with MQL

\begin{tabular}{lccccc}
\hline \multicolumn{1}{c}{ Source } & \multicolumn{1}{c}{$\begin{array}{c}\text { Sum of } \\
\text { Squares }\end{array}$} & DF & $\begin{array}{c}\text { Mean } \\
\text { Square }\end{array}$ & $\begin{array}{c}\text { F- } \\
\text { Value }\end{array}$ & Prob > F \\
\hline Model & 6.000 E-003 & 4 & 1.500 E-003 & 11.25 & 0.0376 \\
A-Depth of cut & 1.800 E-003 & 1 & 1.800 E-003 & 13.50 & 0.0349 \\
B-Feed rate & 3.200 E-003 & 1 & 3.200 E-003 & 24.00 & 0.0163 \\
C-Spindle speed & 2.000 E-004 & 1 & 2.000 E-004 & 1.50 & 0.3081 \\
AC & 8.000 E-004 & 1 & 8.000 E-004 & 6.00 & 0.0917 \\
Residual & 4.000 E-004 & 3 & 1.333 E-004 & & \\
Cor Total & 6.400 E-003 & 7 & & & \\
\hline Pred R-Squared & 0.5556 & \multicolumn{5}{c}{ Adj R-Squared } & 0.8542 \\
Adeq Precision & 9.859 & & & \\
\hline
\end{tabular}


Figure $3 b$ shows the relationship between depth of cut and spindle speed on surface roughness in micromachining with MQL. From the graph, when depth of cut is $0.05 \mathrm{~mm}$ and spindle speed is $2150 \mathrm{rpm}$, the surface roughness is $0.16 \mu \mathrm{m}$. When depth of cut is 0.15 $\mathrm{mm}$ and spindle speed is $2600 \mathrm{rpm}$, the surface roughness is $0.19 \mu \mathrm{m}$. These show that as depth of cut and spindle speed increase; higher surface roughness will result. The empirical model for $R_{a}$ surface roughness for micromilling with MQL is shown by Eqn. 2, where $A=$ Depth of cut $(\mathrm{mm}), B=$ Feed rate $(\mathrm{mm} / \mathrm{min})$, and $C=$ Spindle speed $(1000 \mathrm{rpm})$. The results show a similar outcome to the previous researcher's investigation, where machining with MQL gave better surface roughness compared to dry cutting [19].

$$
\left(R_{a}\right)_{\mathrm{mql}}=0.17-0.9 A+0.04 B-0.038 C+0.5 A C
$$

\section{CONCLUSIONS AND RECOMMENDATIONS}

Through this research, the surface roughness of a machined part has been measured by a surface roughness tester. The values of surface roughness with dry cutting and MQL have been compared. Figure 4 shows the comparison of surface roughness between dry cutting and MQL. The surface roughness with MQL has lower values compared to surface roughness with dry cutting. This proves that the surface roughness with MQL produces better surface roughness compared to dry cutting. The relationship among parameters has been analyzed. For dry cutting, depth of cut, feed rate, and spindle speed are significant factors for surface roughness while for MQL, spindle speed is an insignificant factor and hence has a small influence towards the surface roughness.

For further research, it is recommended that all parameters, such as cutting tool, workpiece materials, and vibration that could influence surface roughness and accuracy should be analyzed. In addition, an optimization of process parameters also should be carried out.

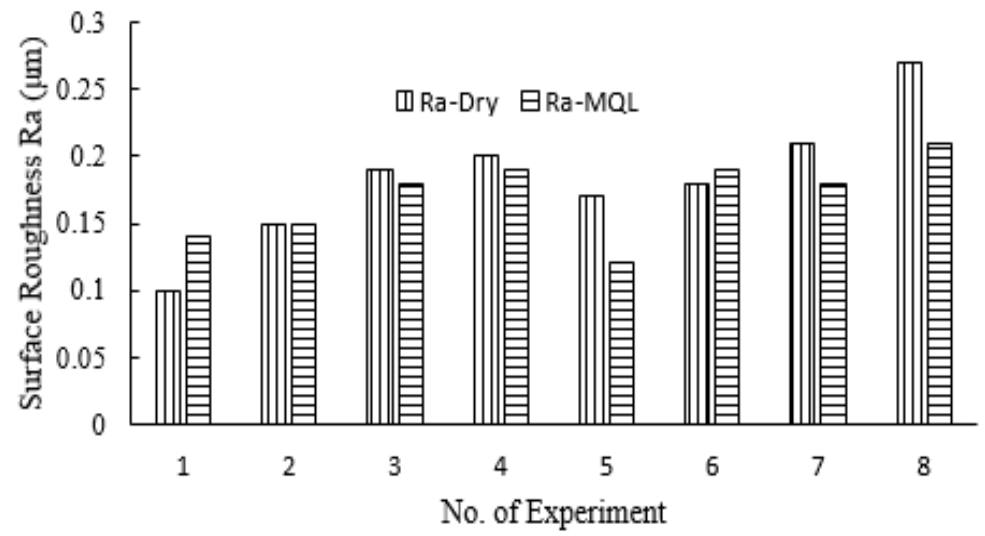

Fig. 4: Comparison of $R_{a}$ surface roughness values obtained from dry milling and milling with MQL.

\section{ACKNOWLEDGEMENT}

The authors would like to express their thanks to the Ministry of Higher Education, Malaysia for their financial support under the Fundamental Research Grant Scheme (FRGS 14-156-0397). 


\section{REFERENCES}

[1] Cheng X, Wang Z, Nakamoto K, Yamazaki K. (2011) A study on the micro tooling for micro/nano milling. International Journal of Advanced Manufacturing Technology, 53:523533.

[2] Wang JS, Gong YD, Abba G, Chen K, Shi JS, Cai GQ. (2008) Surface generation analysis in micro end-milling considering the influences of grain. Microsystem Technologies, 14(7):937942.

[3] Li KM, Wang SL. (2014) Effect of tool wear in ultrasonic vibration-assisted micro-milling. Proceedings of the Institution of Mechanical Engineers Part B Journal of Engineering Manufacture, 228(6):874-855.

[4] Ucun I, Aslantas K, Bedir F. (2013) An experimental investigation of the effect of coating material on tool wear in micro milling of Inconel 718 super alloy. Wear, 300(1):8-19.

[5] Fink J, Thery M, Azioune A, Dupont R, Chatelain F, Bornens M, Piel M. (2007) Comparative study and improvement of current cell micro-patterning techniques. Lab on a Chip, 7(6):672680 .

[6] Kancharla VV, Chen S. (2002) Fabrication of biodegradable polymeric micro-devices using laser micromachining. Biomedical Microdevices, 4(2):105-109.

[7] Shahrom MS, Yahya NM, Yusoff AR. (2013) Taguchi method approach on effect of lubrication condition on surface roughness in milling operation. Procedia Engineering, 53:594-599.

[8] Kajaria S, Chittipolu S, Adera S, Hung WNP. (2012) Micromilling in minimum quantity lubrication. Machining Science and Technology, 16(4):524-546.

[9] Yerkes KL, Dorian J. (1999) Micro-cooler for chip-level temperature control. SAE Technical Paper, 01-1404.

[10] Burton G, Goo CS, Zhang Y, Jun MB. (2014) Use of vegetable oil in water emulsion achieved through ultrasonic atomization as cutting fluids in micro-milling. Journal of Manufacturing Processes, 16:405-413.

[11] Zhong W, Zhao D, Wang X. (2010) A comparative study on dry milling and little quantity lubricant milling based on vibration signals. International Journal of Machine Tools and Manufacture, 50(12):1057-1064.

[12] Machado AR, Wallbank J. (1997) The effect of extremely low lubricant volumes in machining. Wear, 210(1):76-82.

[13] Superkar SD, Clarens AF, Stephenson DA, Skerlos SJ. (2012) Performance of supercritical carbon dioxide sprays as coolants and lubricants in representative metalworking operations. Journal of Materials Processing Technology, 212(12):2652-2658.

[14] Machai C, Iqbal A, Biermann D, Upmeier T, Schumann S. (2013) On the effects of cutting speed and cooling methodologies in grooving operation of various tempers of $\beta$-titanium alloy. Journal of Materials Processing Technology, 213(7):1027-1037.

[15] Shaikh V, Bouberi N, Scharf TW. (2014) Analyzing the effectiveness of microlubrication using a vegetable oil-based metal working fluid during end milling AISI 1018 steel. International Journal of Manufacturing Engineering, 2014: 1-13.

[16] Biermann D, Iovkov I. (2013) Modelling and simulation of heat input in deep-hole drilling with drills and MQL. Procedia CIRP, 8:87-92.

[17] Rakurty CS, Vrela PI, Balaji AK. (2013) Effects of targeted minimum quantity fluid (MQF) application on surface integrity. Procedia CIRP, 8:461-467.

[18] Chae J, Park SS, Freiheit T. (2006) Investigation of micro-cutting operations. International Journal of Machine Tools and Manufacture, 46(3-4):313-332.

[19] Okonkwo UC, Okokpujie IP, Sinebe JE, Ezugwu AK. (2015) Comparative analysis of aluminium surface roughness in end-milling under dry and minimum quantity lubrication (MQL) conditions. Manufacturing Review, 30(2): 1-11. 